\title{
CRITICAL REVIEW ON INDONESIA'S DRAWBACKS AS A PREFERABLE SEAT OF ARBITRATION
}

\author{
Setyawati ${ }^{1}$
}

\begin{abstract}
Indonesia as a developing country is in the urgent need to improve its arbitration law and practice. One of the reasons is because Indonesia may gain many advantages by such improvement, such as: increase of its international reputation as a safe place to invest or conduct trading since there is an assurance that future disputes may be promptly solved through arbitration. One way to improve Indonesia arbitration practice is by creating the jurisdiction as a friendly place to arbitrate, which firstly shall be analysed by reviewing its drawbacks as a preferable seat of arbitration, specifically on the procedure to enforce arbitral awards and the respective judicial supports to conduct arbitration within the jurisdiction.
\end{abstract}

Keywords: arbitration, seat, Law No. 30 year 1999.

\section{Introduction}

In today's economic world, trade between countries or entities with different nationalities can be considered as customary practice. In relation thereto, disputes will be inevitable since they are the by-products of business. ${ }^{2}$ Difficulties will occur in the methods adopted to resolve disputes in such transactions, due to different nationalities, separate laws governing both parties and reluctance of parties to resolve disputes through court in any particular country. ${ }^{3}$

To overcome such difficulties, arbitration is chosen and is becoming increasingly popular these days as stated by F.E Klein, 'it is impossible to imagine modern economy without arbitration.' ${ }^{4}$ In the last fifty years, arbitration has become the most preferred method to solve international commercial disputes. As the result of its recognition, states all over the world are attempting to modernise their arbitration law in order to keep up with its rapid development, by way of enacting an act that provided guidance and support for arbitration proceedings in their country and establishing an institution that

${ }^{1}$ Indonesian advocate and law practitioner, Assistant Lecturer of Private Law, Faculty of Law, University of Indonesia. Obtained Bachelor of Law (S.H.) from University of Indonesia (2006), Master of Law (LL.M.) from University College London, United Kingdom (2010), and registered as a certified Member of Chartered Institute of Arbitrator (MCIArb) (2013), United Kingdom. This paper is part of my dissertation to obtained a LL.M degree.

${ }^{2}$ Russell Thirgood (2004), 'International Arbitration: The Justice Business' 21 (4) J.Int'l Arb. p.341.

${ }^{3}$ Ibid. p.341.

${ }^{4}$ Huala Adolf (2002), International Commercial Arbitration, Jakarta: Raja Grafindo Persada. p.1. 
offered arbitration services.

This attempt came from a believe that the prominent name of arbitration is deemed to lead countries where arbitration is taking its seat to some advantages; like tourism, ${ }^{5}$ arbitration will increase the reputation of a country as one being pro-arbitration and a preferred seat of arbitration, which implicitly means that the law certainty and investment climate in that particular country is internationally reputable.

As a developing country actively involved in international trade, it is unavoidable for Indonesia to follow this trend and it shall be said that Indonesia is encouraged to follow such trend. Indonesia has constantly been attempting to improve its arbitration law. At present, Indonesia has enacted Arbitration and Alternative Dispute Resolution Law of 1999 ("Law No.30/1999") that governs all arbitration proceedings conducted in Indonesia and has ratified the New York Convention for international awards enforcement. However, it is still a rare case for Indonesia to be chosen as a seat of international arbitration.

This paper will attempt to identify the rationale that is holding back Jakarta, Indonesia's capital, as the preferred international arbitration seat.

\section{Discuss and Analysis}

\section{A. Theory of Seat of Arbitration}

Arbitration is an informal yet a structured process of resolving disputes outside courts. When it has an international character, such as (a) involving parties which have their place of business in different countries, or (b) dealing with disputes (i) arising out of obligation to be performed, or (ii) connected with subject matter in a different country from the place of business of at least one of the parties, ${ }^{6}$ there will be more than one law or legal rule involved. ${ }^{7}$ One of the laws is Lex Arbitri, a law that will govern the proceeding of the arbitral tribunal itself, which usually differs from the law governing the matter of the disputes. According to Steyn, J, Lex Arbitri means: ${ }^{8}$

"A body of rules which sets a standard external to the arbitration agreement, and the wishes of the parties, for the conduct of arbitration. The law governing the arbitration comprises the rules governing interim measures (e.g Court orders for the preservation or storage of goods), the rules empowering the exercise by the court of supportive measures to assist an arbitration which has run into difficulties (e.g filling a vacancy in the composition of the arbitral tribunal if there is no other mechanism) and the rules providing for the exercise by the Court of its supervisory jurisdiction over arbitration (e.g removing an arbitrator for misconduct)."

Lex Arbitry is derived from the law of seat of arbitration, since arbitration process cannot be said binding unless attached with a particular system

\footnotetext{
${ }^{5}$ Brian J Casey, 'The Place of Arbitration' (Toronto Arbitration Breakfast Meeting Seminar Note), http://www.arbitrationroundtable.com/casey/casey-article.pdf, (accessed 14 July 2009).

${ }^{6}$ Alan Redfern, Martin Hunter, Nigel Blackaby and Constantine Partasides (2004), Law and Practice of International Commercial Arbitration, London: Oxford University Press, p.14-19.

${ }^{7}$ Ibid, p.1.

${ }^{8}$ Ibid, p.93.
} 
of national law. It will govern the proceeding and legality of arbitration proceedings. ${ }^{9}$ Seat, in this context, refers only to the juridical base of the arbitration, not location where meetings or hearings are being held, which may be implied by the word place. ${ }^{10}$ The seat of arbitration maybe chosen through an arbitration agreement, by any arbitral institution chosen by the parties or the arbitral tribunal in the absence of any such designation by the parties. ${ }^{11}$

In addition to the above, the proceeding will also be governed by rules made exclusively for arbitration held in that particular seat (country) and parties will follow those rules as their Lex Arbitry. This theory is called Locus Arbitry. ${ }^{12}$ Therefore, when parties agree that the seat of arbitration be in London, it refers not only to geographical location, but also to the framework of law which will apply, namely the 1996 Act. ${ }^{13}$ Seat of arbitration will play a significant role in relation to enforcement of awards since arbitration awards will have no significant value for parties if they are unenforceable. In order to make this legally enforceable, it has to be made and signed at the seat of arbitration in acknowledgement of their national law governing such arbitration. ${ }^{14}$ The New York Convention links the law where the arbitration was held and the law where the award is made since performance of arbitral awards at times have to be conducted in another jurisdiction due to location of assets needed to meet the awards. Therefore, it is universally agreed that a good seat to arbitrate is a jurisdiction which is prepared to enforce international arbitral awards, and preferably a contracting state of New York Convention because awards rendered in its territory will be enforceable in another foreign jurisdiction. ${ }^{15}$

\section{B. Arbitration in Indonesia Under Law No. 30 year 1999}

Law No.30/1999 as the first modern arbitration law in Indonesia has several interesting issues to be noted in relation to the international arbitration principle. Firstly, in the world of international arbitration, each contracting state is welcome to determine which matters can be resolved by arbitration and by national courts based on the political, social, and economic considerations. ${ }^{16}$ Indonesian arbitration law was constructed to limit its arbitrability only to commercial matters. ${ }^{17}$

Secondly, the Law No. 30/1999 does not follow the UNCITRAL Model law. It is mostly composed based on the extension of rules in Code of Civil Procedure ("CCP") and arbitration practice in Indonesia. ${ }^{18}$ Nevertheless, it basically holds the same principles and views as the model law, ${ }^{19}$ such as: the

${ }^{9}$ F.A Mann in William W Park (1983), 'Lex Loci Arbitry and International Commercial Arbitration' 32 ICLQ 23.

${ }^{10}$ Redfern, Op cit. p.321.

${ }^{11}$ Arbitration Act 1996, s (3).

${ }^{12}$ Redfern, Op cit. p.98.

${ }^{13}$ Ibid. p. 100.

${ }^{14}$ United Nation Commission on International Trade Law ("UNCITRAL") Arbitration Rules (Adopted 28 April 1976), Art. 16(4).

${ }^{15}$ Redfern, Op cit. p.322.

${ }^{16}$ Ibid. p.164.

${ }^{17}$ Law No.30/1999 Art. 5(1).

${ }^{18}$ Huala Adolf. Op cit. p.132.

${ }^{19}$ Ibid. p.132. 
Law expressly states that the court should respect the parties wishing to solve their disputes through arbitration and will not interfere in such proceedings, ${ }^{20}$ the Law acknowledges that arbitral awards are final and binding and can be enforced as being equivalent to court decisions, ${ }^{21}$ the Law honours parties autonomy in deciding which arbitration rules they wish to follow. ${ }^{22}$ Furthermore, in order to promote promptness of arbitration, the Law even establishes that any arbitration proceeding shall be settled within 180 days since the arbitral tribunal is made. ${ }^{23}$ Therefore, it can be said that Law No. 30/1999 comprises the elements of a contemporary and satisfactory lex arbitry. ${ }^{24}$

Thirdly, international arbitration requires a clear distinction between international and domestic arbitration. ${ }^{25}$ The need stands for a dogma which states that international commercial dispute resolutions should be fully accommodated by a particular seat and there shall be a distinction between international and domestic disputes resolutions. ${ }^{26}$ Looking at Indonesia arbitration law as lex arbitry is quite an interesting case. It is a dualist in its face, which means that it differentiates between domestic and international arbitration. ${ }^{27}$ However, it does not separate procedures between domestic and international arbitration and is merely a separation that will not make such law, dualist. ${ }^{28}$

Lastly, there are no articles in the Law that point out the meaning of international arbitration. Article 1 (9) of Law No.30/1999 merely mentions the definition of international arbitral award. Moreover, the Law, strangely, only addresses recognition of such award in Indonesia without establishing any detailed procedures to hold such proceedings in Indonesia. ${ }^{29}$

\section{Indonesian National Board of Arbitration ("BANI")}

Established in 1977, BANI is the main institution and arbitration player in Indonesia. The arbitrators in BANI are mostly Indonesians, since article 9 (5) of the BANI rules ("BANI Rules") mentions that, in the event an arbitration proceeding is governed by Indonesian law, it is recommended that the arbitral tribunal comprise at the very least one Indonesian arbitrator who has Indonesian law background. However, around 30\% of its arbitrators come from foreign nationals in order to accommodate the needs of every client.

BANI has rather unique procedures. According to article 20 (1) of BANI Rules the parties shall try to seek for an amicable resolution through a mediator or third parties. In case the parties have achieved mutual agreement, the tribunal will then write that consensus in a memorandum which will be final and bind the parties in a similar way as an arbitral award..$^{30}$ This is in

${ }^{20}$ Law No.30/1999 Art. 3, Art.11(2).

${ }^{21}$ Law No.30/1999 Art. 60.

${ }^{22}$ Law No.30/1999 Art. 31(1).

${ }^{23}$ Law No.30/1999 Art. 48(1).

${ }^{24}$ Jan K Schaefer (2000), 'Leaving the Colonial Arbitration Laws Behind: South East Asia's Move into the International Arbitration Arena' 16 (3) Arb. Int'l 297-332.

${ }^{25}$ Ibid, p.299.

${ }^{26}$ Ibid, p.299.

${ }^{27}$ S.R Luttrell (2007), 'Lex Arbitri Indonesia: the Law, Practice and Place of Commercial Arbitration in Indonesia Today' 10 (6) Int. A.L.R. 190-205. p.197.

${ }^{28}$ Ibid. p.197.

${ }^{29}$ Law No.30/1999 Art. 65.

${ }^{30}$ BANI Rules Art. 20 (2). 
accordance with its purpose to provide an independent service and neutral alternative dispute resolution in commercial matters to support law enforcement in Indonesia. Furthermore, to ensure efficiency and effectiveness of the proceeding, BANI regulates that the tribunal shall have the decision within 180 days unless matters are further complicated hence making it necessary for the tribunal to extend the period with mutual permission of both parties. ${ }^{31}$ In addition, BANI gives freedom to the parties to decide their specific procedure as long as it is in compliance with BANI Rules. ${ }^{32}$

BANI claims that it caters for both domestic and international arbitration proceedings held within Indonesia. ${ }^{33}$ In terms of domestic market, BANI shows signs of improvement of being an alternative institution for resolving disputes in commercial matters outside the court. This fact is clearly shown in BANI quarterly newsletter reports regarding the development of arbitration in Indonesia since the promulgation of Law No. 30/1999. The number of cases registered in BANI speak for itself. In the years 1987 up to 1996 there were only 56 cases, however, this number increased significantly to 215 between 1997 and 2007. Moreover, from all the registered cases from 2001 to 2006, $47 \%$ of these cases were solved in less than 90 days and only $12 \%$ was settled in more than 180 days. Unfortunately, from all the cases, 70\% comprised domestic disputes while 30\% comprised international disputes. ${ }^{34}$

\section{Indonesian Drawbacks as a Favourable Seat}

Based on the above descriptions, Indonesia basically has the Law and institution to support its position as a seat in an international arbitration. Nonetheless, as mentioned previously, it seems a rare reality for Indonesia to be chosen as a seat of international arbitration. Therefore, an analysis will be made below pertaining to the obstacles that may be preventing such occurrence.

\section{The Procedures of Enforcement of Arbitral Awards in Indonesia}

The first regulation regarding international awards enforcement is Supreme Court Regulation No. 1/1990. According to this regulation, the Supreme Court is the sole authority in issuing exequatur. ${ }^{35}$ However, in private matters cases, an application shall first be made to the Central Jakarta District Court which will pass on such request to the Supreme Court for receiving exequatur within 14 days. Then, once it is granted, an enforcement order will be sent back to the Central Jakarta District Court for implementation, and the court will then transfer such order to other district courts, if execution should be needed elsewhere.

A new era of arbitration law in Indonesia has only begun following the enactment of Law No.30/1999. This Law introduced a set of procedures

\footnotetext{
${ }^{31}$ BANI Rules Art. 4(7).

${ }^{32}$ BANI Rules Art. 2(j).

${ }^{33}$ BANI Objective (a).

${ }^{34}$ BANI, 'Arbitration Development in Indonesia', (2007) 1 Oct-Dec Indonesia Arbitration Quarterly

${ }^{35}$ Supreme Court Regulation No.1/1990 Art. 4.
} Newsletter 4. 
concerning enforcement of domestic and international arbitral awards. The new Law does not repeal the enforcement procedures set-up in the Supreme Court Regulation No.1/1990. However, if the regulations in the new Law differ from the Supreme Court Regulation, the new Law will prevail since it is ranked higher in the Indonesia law sources compared to the Supreme Court Regulations. ${ }^{36}$

The new Law basically provides adequate guidance for both international and domestic enforcement procedures in Indonesia. Nonetheless, there are several things that have to be taken into considerations when analyzing whether or not Indonesia is an amiable place to arbitrate in terms of enforcement of awards.

\section{A. Time Limit}

One of the main objectives of arbitration is to provide a final and binding alternative dispute resolution which can be enforced internationally within a faster time frame than having to enforce foreign judgement in another jurisdiction. ${ }^{37}$ Time limit is extremely important because the faster awards are being enforced, the sooner the winning parties will acquire law certainty regarding their rights. Time limit is normally established in the national arbitration law and will differ from country to country. ${ }^{38}$ The absence of time limit in national legislation will create fear that the court will not give exequatur promptly and parties can only rely on the judge's good deeds. This kind of approach certainly will make such jurisdiction non preferable as a seat of arbitration.

However, the absence of time limit in the enforcement process of international arbitral awards in Indonesia arbitration law does not make the court defer issuance of exequatur. According to Karen Mills, since the new Law came into effect in 1999 the issuance of exequatur for international awards has been faster. Before the new Law, enforcement orders for domestic awards would take up to 6 months but since the new Law was promulgated issuances of exequatur took less than a month. ${ }^{39}$ According to her record out of 16 cases registered in the Central Jakarta District Court, 9 have been given exequatur and from these 9 cases, five of them were given in a timely manner. ${ }^{40}$ She also added that the court places priority to issuance of exequatur for international awards rather than the domestic ones.

\section{B. Record of Awards Enforcement}

Attention shall be given to the domestic enforcement record in Indonesia. The reason is because when international parties decided to choose Indonesia as seat of their arbitration, Indonesian arbitration law will govern the process of arbitration. Then, the awards that are to be rendered will be considered as domestic awards (Territory Position Principle). Therefore, it is

${ }^{36}$ Karen Mills, 'Enforcement of Arbitral Award in Indonesia \& Other Issues of Judicial Involvement in Arbitration' (the up-dated version of paper that was being presented at the Inaugural International Conference of Arbitration of the Malaysia Branch of the Chartered Institute in Kuala Lumpur) 1/3 2003) http:// www.arbitralwomen.org/files/publication/4310102632224.pdf (accessed 19 July 2009). p.3.

${ }^{37}$ Arbitration Act 1996 s 1 (a).

${ }^{38}$ Redfern, Op cit. p.519.

${ }^{39}$ Karen Mills, Op cit. p.5.

${ }^{40}$ Ibid. p.8. 
the record of domestic procedures that shall be take into account before parties decide to choose Indonesia as their seat.

Law No. 30/1999 clearly protect and support the enforcement process for domestic awards, namely: time limit, ${ }^{41}$ stating that arbitration awards are final and bind both parties ${ }^{42}$ and instant execution if the losing party will not voluntarily perform the awards..$^{43}$ In addition, the new Law gives the authority to issue an enforcement order directly to the Head of the district court which means that execution will commence in due course, since there is no need to receive exequatur from the Central Jakarta District Court. Nonetheless, there might be difficulties in measuring enforcement records in Indonesia. The reason is because, as a civil law country, Indonesian courts are not required to follow precedence from previous cases. As a consequence thereof, there are no customs in reporting and compiling law cases as usually conducted in common law countries. ${ }^{44}$ Most of the times, cases that were reported or discussed in law journals, for example: Varia Peradilan, are only those that are important. Therefore, it is difficult to predict how many cases have been executed by court in the arbitration area. It is even more difficult given the fact that the domestic awards are registered directly in courts with jurisdiction over the respondent, since Indonesia is a huge state with 292 judicial districts spread over the Indonesian archipelago of around 15 thousand islands. ${ }^{45}$

The above realities probably explain why it seems that there are only few arbitrations proceedings conducted in Indonesia, since even though there are many of them, such facts will not be properly recorded, reported, or widely published. This reality possibly defers the intention of parties to choose Indonesia as their seat since they only have few comparisons of such proceedings in Indonesia. Nevertheless, it seems that the development of arbitration practice in Indonesia is quite positive since based on the survey conducted by Karen Mills of Indonesian leading practitioners, most of the domestic awards were executed by district courts in a timely manner and without any hindrances. ${ }^{46}$

\section{Judicial Supports}

Another matter that needs to be taken into consideration before parties decide to choose a seat of arbitration is judicial support in conducting arbitration efficiently and effectively. ${ }^{47}$ Alan Redfern and Martin Hunter specify that one of the main reasons why judicial supports are important is because the success of international arbitration proceedings in a particular country will largely depend upon the national arbitration law. ${ }^{48}$ The judicial supports to the conduct of arbitration will usually be stipulated in the national law, such as: section 44 (1) of the 1996 Act, which provides the court the same power to

\footnotetext{
${ }^{41}$ Law No.30/1999 Art.59(4).

${ }^{42}$ Law No.30/1999 Art.60.

${ }^{43}$ Law No.30/1999 Art.61.

${ }^{44}$ Karen Mills, Op cit. p.4.

45 Ibid. p.4.

46 Ibid. p.4.

${ }^{47}$ Redfern, Op cit. p.323.

${ }^{48}$ Ibid. p.96.
} 
order an inspection, custody or detention. However, too much assistance from the courts will not be desirable by parties in arbitration, since it may create an intervention and intervene in the independence of proceedings. ${ }^{49}$ Therefore, it is an occurrence of true partnership between the courts and the arbitral tribunals that is sought by parties when choosing a seat of arbitration.

In addition to the above, it is obvious that during the process of an arbitration proceeding, an ideal judicial system will only offer its help and will not intrude in the process. Redfern stating that, both practitioners and parties involved in a proceeding would feel secure if they know that they are conducting arbitrations in a seat where the courts fully support the proceedings. ${ }^{50}$

Based on the above description, this section will focus on the judicial supports towards arbitration proceedings held in Indonesia.

\section{A. Arbitration Proceeding Independency}

Article 2 of Law No.30/1999 stipulates that it will govern any dispute where the parties have agreed in written to solve such through arbitration since consensus of both parties is a strict requirement to the validity of a contract. $^{51}$ Furthermore, article 3 specifically mentions that Indonesian courts would have to state that they have no jurisdiction over disputes which already have an arbitration agreement therein. In addition, article 11 (1) of the new Law regulates that in the occurrence of arbitration clause in agreements, it will eliminate the rights of the parties to solve disputes through courts.

The above, however, is not always the case. Courts may take over the arbitrator's jurisdiction, even if there is an agreement to arbitrate as an integral part of the whole agreement. It can be seen in the case of PT Perusahaan Dagang Tempo v PT Roche Indonesia. ${ }^{52}$ PT Perusahaan Dagang Tempo acted as the sole distributor of (i) Over The Counter ("OTC") and (ii) prescription ("Rx"), two products of PT Roche Indonesia ("Principal"). There is an arbitration clause included in the contract. The principal on 31 August 1999 terminated the distribution contract based on the article in the contract which stated that termination is allowed through submitting a 6 months prior notice.

Then, the Distributor filed suit against such termination before the District Court of South Jakarta. The Principal opposed the lawsuit, and submitted that the District Court had no jurisdiction to solve the dispute since there was an arbitration clause in the agreement. The court rejected the Principal's argument and decided that it had jurisdiction over the case. Moreover, it ordered a freeze on the Principal assets on the basis that partial termination can be classified as an act of tort and was included in the jurisdiction of the court not arbitration. Furthermore, the court held that arbitrators could only resolve disputes, which related to technical and business matters.

This case was brought to the court when Law No.30/1999 was already in effect. The act of the court clearly opposed articles 3 and 11 of the new Law and showed inadequate understanding of the new arbitration law and unsupportive behaviour towards arbitration proceedings.

\footnotetext{
${ }^{49}$ Ibid. p.388.

${ }^{50}$ Ibid. p.398.

${ }^{51}$ Indonesian Civil Code Art.1320.

52 454/Pdt.G/1999/PN.JakSel (30 May 2000).
} 


\section{B. Securing the Attendance of Witness and Experts}

Law No. 30/1999 is a modern arbitration law which provides great authority to arbitration tribunals in conducting a proceeding. Article 32 stipulates that the arbitration tribunal is authorized to issue provisional awards or interlocutory decisions pursuant to the request of one party to control the examination procedures. Furthermore, the Law also authorizes the tribunal to summon witnesses or before the tribunal if requested by one party and order both parties to provide evidence in support of their positions..$^{53}$ Nevertheless, it is so unfortunate that there are no articles in the new Law that stipulate about judicial assistance if the orders issued by tribunals were not conducted voluntarily by the parties or in the event witnesses refuse to be summoned to court.

Article 630 Reglement op de Rechtsvordering ("RV") as the old aebitration law provides a mechanism for the court to summon a witness who is unwilling to attend the arbitration proceeding. However, the new Law supersedes the old rules from RV; unfortunately, it does not provide new procedures as a substitution. ${ }^{54}$ Therefore, in the event where a witness refuses to come before the tribunal, the new Law provides neither mechanism for the tribunal to request orders from courts in securing the attendance of witness or expert nor imposes such act as being against the law.

Interestingly, Law No.30/1999 still applied CCP as Lex Arbitry to govern the evidence and witness rules in an arbitration proceeding as presented in article 46 (3) and article 37 (3). Therefore, it is actually possible for the tribunal to request orders from the court in order to present witnesses before the tribunal in accordance with article 139-143 CCP. Pursuant to these rules, an authorized employee of the court shall summon witnesses who refuse to appear before the court and if they should still refuse, they will then be obliged to pay any expenses incurred. Then, in the extreme case where they still refuse to appear, the head of that particular district court will be authorized to report them to the police.

Nevertheless, the application of the above procedure will solely depend on the discretion of the courts, since there is no strict obligation imposed on the courts by Law No.30/1999 to assist with the arbitration proceedings. This fact is clearly unfortunate for arbitration proceedings conducted in Indonesia and parties obviously will hesitate to have a seat where they can only rely on the good deeds of judges in supporting their proceedings.

\section{Annulment of Awards}

In the event when one of the arbitration parties has submitted the awards to be enforced at the relevant district court, but the counter-party believes that there have been mistakes or forgeries in the letters or documents submitted during the hearings, or one of the party discovered that decisive documents were being deliberately concealed, or a fraud was committed by one of the parties in dispute, then the concerned party may submit an application for annulment to the Head of District Court as stipulated in article 70 of Law No.30/1999.

The annulment application shall be submitted in writing within 30 days

${ }^{53}$ Law No.30/1999 Art. 46(3), Art. 49(1).

${ }^{54}$ S.R Luttrell. Op cit. p. 190-205. 
since the awards were registered at the district court then the Head of that district court shall decide whether to grant or reject the annulment application within 30 days since its submission..$^{55}$ Furthermore, there is still recourse to submit an appeal to the Supreme Court, if the party does not agree with the decision of the Head of District Court and decision of such appeal shall be rendered within 30 days since the application was received. ${ }^{56}$

It shall be noted that, since the application can only be made after the awards are being registered for enforcement, court will shall only examine reasons submitted in relation to the annulment application as stated in article 70 of the new Law, without any attempt to examine the merit of the disputes which is the jurisdiction of the arbitrators. ${ }^{57}$ In addition, to support the application, court decisions as evidence regarding the allegation of forgery, fraud, or concealment shall be strictly applied. ${ }^{58}$

Nevertheless, the case of PT Krakatau Steel $v$ International Piping Product $I n c^{59}$ showed a rather inapprehensive approach to the meaning of article 70 and its elucidation. PT Krakatau Steel ("Buyer") and International Piping Product Inc ("Seller") entered into a Sales and Purchase agreement ("SPA"). The goods were shipped prior to issuance of Letter Credit and the Buyer refused to accept the goods since they did not comply with the specifications Buyer had requested in a letter sent one month before the delivery. Based on such reason, the Buyer was in the opinion that the SPA was thus null and void.

The Seller took the case before an ad-hoc arbitration in Jakarta under UNCITRAL rules, claiming that they had no obligation since they did not receive any Bill of Lading and asserting that the Buyer had breached the Agreement. Moreover, they asked for compensation for their losses and alleged that the Buyer had forged and falsified signatures. The tribunal decided: (i) there was no forgery since the signatory had testified that all the signatures were original, (ii) The SPA was binding on both parties since at the time of execution, the SPA met all the specifications, thus, supersedes the previous enquiry, (iii) The Buyer had no right to receive a Bill of Lading since the Buyer did not issue Letter of Credit, refused the goods, and refused the documents.

The Buyer was dissatisfied with the award, and attempted for annulment of the award based on article 70 to the South Jakarta District Court. The court granted the Buyer's request on the following basis: (i) the elucidation of article 70 was only advisory, so the court was allowed to question such signatures as forgery, (ii) since the Seller did not carry out his obligation to deliver the shipping documents, he concealed such documents (iii) there was fraud committed by the Seller since the Seller did not meet the specifications requested by the Buyer in his letter of enquiry.

This case shows how the courts in Indonesia still have to improve their understanding pertaining to arbitration law and appreciation regarding the finality of arbitral awards. The ideal court will highly respect the finality of awards and set a very strict standard and requirement in granting annulment of such. Furthermore, the approaches of the courts as showed by this case shall be carefully evaluated since as mentioned previously, enforcement of

\footnotetext{
${ }^{55}$ Law No.30/1999 Art. 72 (3).

${ }^{56}$ Law No.30/1999 Art. 72 (5).

${ }^{57}$ Law No.30/1999 Art. 62 (4).

${ }^{58}$ Law No.30/1999 Elucidation of Art.70

59 282/Pdt/2002/PN.Jak.Sel (South Jakarta, Indonesia, District Court).
} 
awards constitutes one of the devices to promote Indonesia as a preferred seat of arbitration and if courts easily grant annulment without evidence there will be a doubt whether Indonesia would be a pro-arbitration seat that is friendly in enforcing awards or not.

\section{Conclusion}

To conclude, Indonesian arbitration law is actually adequate to secure and support both international and domestic awards enforcement within its jurisdiction, despite the premature age of its arbitration law and unavailability of time limit for the Central Jakarta District Court to grant exequatur. Moreover, the improvement of BANI works and several executions of arbitral awards by Indonesian district courts are evidence that there has indeed been a development of arbitration practice in Indonesia. These two facts clearly show bright hope that Indonesia may become an active player in the world of international arbitration, and in particular, become a favourable seat.

Unfortunately, the absence of widely published and well-recorded domestic awards enforcement in Indonesia has convinced the international arbitration world to assume that there are only limited numbers of arbitration proceedings conducted within the jurisdiction and consequently they hesitate to choose Indonesia as their preferable seat. Furthermore, the primary drawbacks of Indonesia in becoming a favourable country to arbitrate are its lack of judicial assistance and inadequate encouragement to nudge judges towards arbitration proceedings.

Therefore, an improvement should be carried out to create a supportive judicial system as well as developed responsive and pro-arbitration judges. The best starting point of advancement for Indonesian arbitration practice can be done by firstly, inserting articles in Law No. 30/1999 that impose obligations on the courts to assist arbitration proceedings in particular in securing the appearances of witnesses and experts. Furthermore, there is an urgent need to establish higher requirements or standards to annul or reject arbitral awards such as: to be only limited to serious irregularities or lack of jurisdiction by the tribunal.

\section{Bibliography}

\section{Books:}

Huala, Adolf (2002), International Commercial Arbitration, Jakarta: Raja Grafindo Persada.

Redfern H, Martin Hunter, Nigel Blackaby and Constantine Partasides (2004), Law and Practice of International Commercial Arbitration, London: 0xford University Press. 


\section{Articles:}

BANI, 'Arbitration Development in Indonesia', (2007) 1 Oct-Dec Indonesia Arbitration Quarterly Newsletter 4.

Casey B J, 'The Place of Arbitration' (Toronto Arbitration Breakfast Meeting Seminar Note), http://www.arbitrationroundtable.com/casey/caseyarticle.pdf, (accessed 14 July 2009).

Luttrell S R, 'Lex Arbitri Indonesia: the law, practice and place of commercial arbitration in Indonesia today' (2007) 10(6) Int. A.L.R.

Mills K, 'Enforcement of Arbitral Award in Indonesia \& Other Issues of Judicial Involvement in Arbitration' (the up-dated version of paper that was being presented at the Inaugural International Conference of Arbitration of the Malaysia Branch of the Chartered Institute in Kuala Lumpur) 1/3 2003) http://www.arbitralwomen.org/files/publication/4310102632224.pdf (accessed 19 July 2009).

Park W W, 'Lex Loci Arbitry and International Commercial Arbitration' (1983) 32 ICLQ.

Schaefer J K, 'Leaving the Colonial Arbitration Laws Behind: South East Asia's Move into the International Arbitration Arena' (2000) 16 (3) Arb. Int'l 297-332.

Thirgood R (2004), 'International Arbitration: The Justice Business', 21 (4) J.Int'l Arb.

\section{Cases:}

Ascom Electro AG v P.I Manggala Mandiri Sentosa W.7DC.Ht.02/Pdt.Eks/Abt. Int/1993.03 (22 September 1993).

PT Krakatau Steel v International Piping Product Inc 282/Pdt/2002/PN.Jak. Sel.

PT Perusahaan Dagang Tempo v PT Roche Indonesia 454/Pdt.G/1999/PN Jak.

Sel (30 May 200). 